\title{
HERMETIA ILLUCENS ASPEK FORENSIK, KESEHATAN, DAN EKONOMI
}

\author{
Sunny Wangko \\ Bagian Anatomi dan Histologi Fakultas Kedokteran Universitas Sam Ratulangi Manado \\ Email: sunnywangko@yahoo.com
}

\begin{abstract}
Hermetia illucens (Diptera: Stratiomyidae) is distributed throughout the temperate and tropic areas. Adults only need water to survive and are not attracted to human habitation or foods. Generally, adult females oviposit on organic waste of plants, animals, or humans. Larvae have 6 instars which make $H$. illucens applicable for the estimation of postmortem interval (PMI) at late-stage decomposition. Albeit, the consideration of environmental conditions is significantly needed for obtaining more accurate PMIs. Larvae of Hermetia illucens are useful in bioconversion of organic waste and can reduce the pollution of animal and human manure in a relative short time. Moreover, larva population can inhibit Musca domestica population and several kinds of microbes. The high nutrient content of these larvae make them suitable as animal food. Studies involving geographical, environmental, and seasonal conditions have to be developed to support the usage of Hermetia ilucens more accurately.
\end{abstract}

Keywords: Hermetia illucens, postmortem interval, antimicrobial, bioconversion, animal food

\begin{abstract}
Abstrak: Hermetia illucens (Diptera: Stratiomyidae) tergolong serangga yang umum ditemukan di daerah berikllim sedang dan tropis. Serangga dewasa hanya memerlukan air untuk mempertahankan hidup dan tidak tertarik pada habitasi atau makanan manusia. Umumnya dewasa betina beroviposisi pada sampah organik baik yang berasal dari tumbuhan, hewan, maupun manusia. Perkembangan larva sampai instar 6 memungkinkannya diaplikasikan untuk perkiraan postmortem interval pada tahap dekomposisi lanjut dengan mempertimbangkan kondisi lingkungan di suatu daerah tertentu untuk mendapatkan PMI yang lebih akurat. Larva Hermetia illucens sangat bermanfaat dalam biokonversi sampah organik dan menurunkan polusi lingkungan akibat kotoran hewan dan manusia dalam waktu yang relatif singkat. Selain itu, populasi larva dapat menekan populasi Musca domestica, serta pertumbuhan berbagai jenis mikroba. Kandungan nutrien yang tinggi dari larva Hermetia illucens membuatnya ideal sebagai pakan ternak. Penelitian pada berbagai kondisi geografik, lingkungan, dan musim perlu dikembangkan agar pemanfaatan Hermetia illucens dapat diaplikasikan secara lebih akurat.
\end{abstract}

Kata kunci: Hermetia illucens, postmortem interval, antimikroba, biokonversi, pakan ternak

Hermetia illucens (Linnaeus, 1758) termasuk famili Stratiomyidae yang umum ditemukan di daerah beriklim sedang dan tropis. ${ }^{1-6}$ Serangga dewasa tidak termasuk hama dan hanya membutuhkan air untuk mempertahankan hidup dan bereproduksi. ${ }^{3,6-9}$ Perkembangan larva sampai instar $6^{10}$ memungkinkan serangga ini dipakai untuk menentukan waktu kematian pada mayat yang telah mengalami dekomposisi lanjut. Laporan kasus dan penelitian hewan coba menunjukkan bahwa $H$. illucens ditemukan berkolonisasi baik pada mayat maupun bangkai hewan coba. ${ }^{11-14}$

$H$. illucens sangat berperan dalam biokonversi sampah organik tumbuhan, 
hewan, maupun manusia, secara alamiah atau dengan perlakuan tradisional. ${ }^{6,10,15,16}$ Larva bersifat sangat rakus ${ }^{17}$ dan dapat menurunkan volum massa sampah dan kotoran secara bermakna sampai 42$56 \% .{ }^{18,19}$ Larva mengandung tinggi protein dan lemak, serta asam amino esensial yang lengkap sehingga sesuai digunakan sebagai pakan ternak. ${ }^{20,21}$

Larva $H$. illucens dapat menekan pertumbuhan populasi Musca domestica sampai $94-100 \% .^{22,23}$ Produk larva dilaporkan berefek antimikroba. Penelitian terhadap efek tersebut menunjukkan bahwa populasi larva dapat menghambat mikroba tertentu, antara lain: Salmonella spp, ${ }^{18}$ Klebsiella pneumoniae, Neisseria gonorrhoeae, Shigella sonnei tetapi tidak terhadap beberapa jenis bakteri Gram positif. ${ }^{24}$

Secara alamiah oviposisi $H$. illucens terjadi pada sampah, kotoran hewan atau manusia, serta bahan organik lainnya yang mengalami pembusukan sehingga pada permukaan tubuh larva dan bagian ususnya ditemukan mengandung mikroba tertentu. 22,23,25 Dalam pemanfaatan larva untuk pakan ternak yang selanjutnya akan masuk dalam rantai makanan, perlu dilakukan pemrosesan khusus terhadap mikroba patogen agar larva tidak menjadi karier dan mengakibatkan terjadinya penyakit infeksi baik pada ternak maupun manusia. ${ }^{25}$

\section{HERMETIA ILLUCENS}

\section{Famili Stratiomyidae}

Famili Stratiomyidae merupakan kelompok yang cukup besar dengan sekitar 260 spesies yang telah dikenal di Amerika Utara. Famili ini tidak termasuk golongan hama dan umumnya sering ditemukan di sekitar bunga-bungaan. ${ }^{26}$

\section{Hermetia illucens (Diptera: Stratio- myidae) bentuk dewasa dan larva}

Hermetia illucens, dikenal juga sebagai black soldier fly, ditemukan pada hampir semua daerah beriklim sedang dan tropis tersebar di seluruh dunia. ${ }^{1-6}$ Dewasa berukuran sedang - besar, tampak seperti lebah (wasplike), ${ }^{1,26}$ dan hanya membutuhkan air untuk mempertahankan hidup; cadangan nutrien untuk bereproduksi telah diperoleh pada saat larva. ${ }^{3,6,7,9,21} H$. illucens betina sering ditemukan sekitar sampah organik, seperti kotoran hewan atau tumbuhan yang telah membusuk, untuk beroviposisi. ${ }^{8}$

$H$. illucens dewasa berukuran panjang 15-20 mm dan berbentuk pipih (Gambar 1A). Tubuh betina seluruhnya berwarna biru-hitam, sedangkan pada yang jantan warna abdomen lebih coklat. Pada kedua jenis kelamin, ujung-ujung kaki berwarna putih dan sayap berwarna hitam kelabu, dilipat datar pada punggung saat istirahat. $^{1,27}$ Abdomen berbentuk memanjang dan menyempit pada basis, dengan 2 segmen pertama memperlihatkan daerah translusen.,27,28 Venasi sayap tersusun padat dekat costa dan lebih berpigmen dibandingkan bagian belakang, sedangkan vena $C$ tidak seluruhnya mengitari sayap. ${ }^{27}$
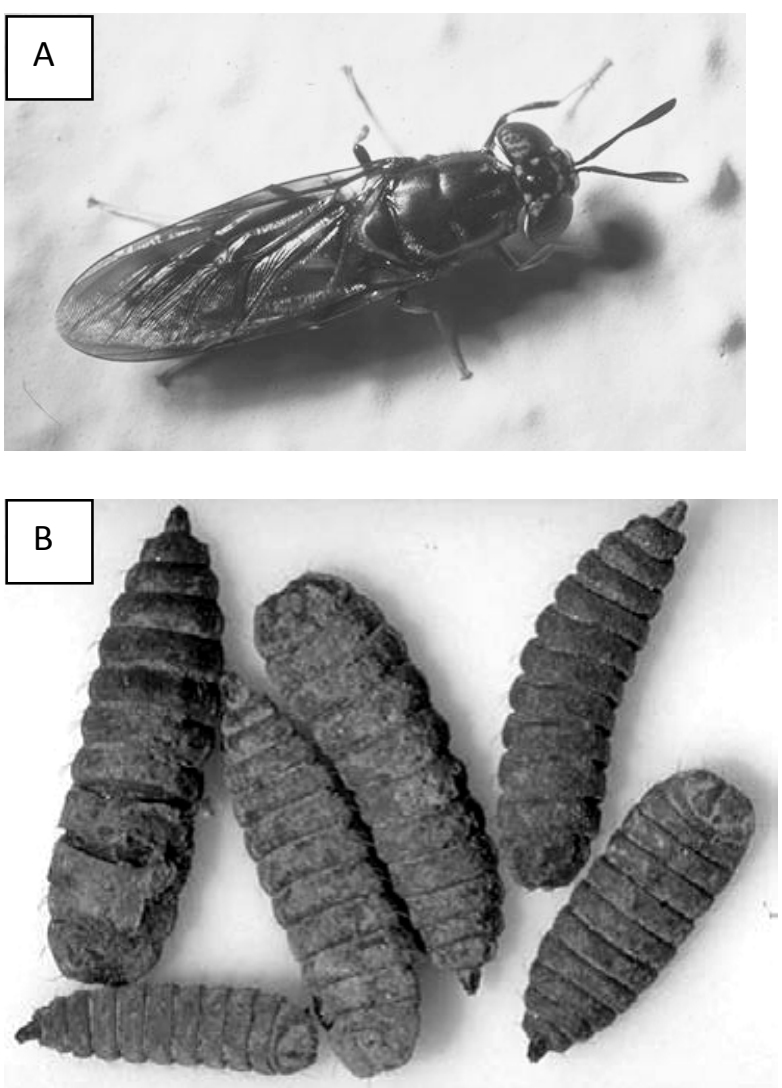

Gambar 1. Hermetia illucens. A, Serangga dewasa. B, Larva. Sumber: DuPonte \& Larish, 2003. 


\section{ASPEK FORENSIK}

Entomologi forensik adalah bidang ilmu yang mempelajari serangga dan pemanfaatannya dalam penyidikan baik medikolegal, urban, atau stored product. Dari aspek medikolegal, pemanfaatan entomologi forensik ditujukan untuk perkiraan postmortem interval (PMI) berdasarkan perkembangan serangga yang ditemukan pada mayat. 12,2,30 $^{2}$

Selama tenggang waktu 72 jam pertama setelah kematian, umumnya seorang ahli forensik dapat menentukan PMI secara akurat berdasarkan kondisi tubuh mayat, termasuk tanda-tanda kematian yang ditemukan. ${ }^{31-35}$

Setelah melewati tenggang waktu 72 jam, informasi medik yang dapat digunakan seorang ahli forensik untuk penentuan PMI menjadi sangat terbatas. Pada keadaan demikian, seorang ahli entomologi forensik diharapkan dapat memberikan perkiraan PMI berpatokan pada fase siklus hidup serangga forensik tertua yang ditemukan pada mayat (suksesi serangga forensik). ${ }^{35,36}$

Patokan awal perkiraan PMI sering disamakan dengan period of insect activity (PIA) atau time of colonization (TOC) yaitu saat serangga yang pertama beroviposisi atau meletakkan larvanya pada mayat tersebut, walaupun sebenarnya terdapat jedah waktu antara saat kematian dan saat oviposisi atau peletakan larva. Patokan akhir PMI yaitu saat penemuan mayat dan pengenalan fase siklus spesies tertua yang berkolonisasi. ${ }^{35-37}$ Identifikasi spesies yang tepat sangat dibutuhkan agar tidak terjadi kesalahan estimasi TOC atau PMI. ${ }^{1,33,34}$

Durasi perkembangan larva $H$. illucens untuk suatu daerah tertentu diperlukan untuk perkiraan PMI pada proses penyidikan. $H$. illucens termasuk kelompok yang berkolonisasi pada fase dekomposisi lanjut. ${ }^{11}$ Berbagai studi mengenai perkembangan larva melaporkan hasil yang bervariasi. Tomberlin et al. ${ }^{12}$ menggunakan hewan coba Sus scrofa L. di Tifton, Georgia dan melaporkan $H$. illucens beroviposisi pada bangkai di hari ke-6 dan larva prepupa ditemukan di hari ke-54. Ndueze et al. ${ }^{13}$ menggunakan beberapa jenis hewan coba di Nigeria mendapatkan $H$. illucens dewasa pada bangkai di hari ke2 dan 3 . Wangko ${ }^{14}$ melaporkan terdapatnya $H$. illucens dewasa hari ke-5 pada bangkai babi domestik di Manado.

Perkembangan sejak telur sampai stadium prepupa dapat bervariasi tergantung sumber makanan dan kondisi lingkungan. $^{12}$ Di New Zealand, May ${ }^{38}$ melaporkan perkembangan larva terjadi 31 hari pada suhu $27,8^{0} \mathrm{C}$. Tomberlin et al. ${ }^{3}$ meneliti perkembangan larva dengan pemberian 3 jenis diet dan mendapatkan perkembangan dari telur sampai serangga dewasa membutuhkan sekitar 43 hari Tomberlin et al. ${ }^{5}$ juga meneliti pengaruh suhu $\left(27,30\right.$, dan $36^{\circ} \mathrm{C}$ ) terhadap perkembangan larva $H$. illucens dan mendapatkan 41,6 hari dengan perkiraan waktu 4 hari untuk menetasnya telur. Wangko ${ }^{14}$ mendapatkan bahwa pada suhu ruang $28-29^{0} \mathrm{C}$ dengan fluktuasi harian $1^{0} \mathrm{C}$ dan kelembaban berkisar 62-66\%, H. illucens dewasa generasi kedua ditemukan pada hari ke 35-39 hasil rearing sampel tanah yang menunjukkan telah terjadinya kolonisasi pada hewan coba. Zakova ${ }^{6}$ melaporkan perkembangan larva $H$. illucens pada sampah organik sekitar 35-an hari. PujolLuz et al. ${ }^{29}$ melaporkan pemanfaatan $H$. illucens dalam penyidikan kasus kematian dalam keadaan dekomposisi lanjut di Amapa, Brazilia. Waktu perkembangan larva yang dipakai yaitu 42 hari dengan mempertimbangkan suhu saat kejadian.

Mengingat perkembangan larva yang membutuhkan waktu cukup panjang untuk mencapai instar 6 (dibandingkan blow fly dengan instar 3 sehingga dipakai untuk perkiraan PMI pada dekomposisi lebih dini) dan durasi waktu yang cukup bervariasi maka dalam pemanfaatan $H$. illucens untuk perkiraan PMI perlu diketahui durasi waktu yang dibutuhkan untuk perkembangan larva pada suatu daerah tertentu dengan mempertimbangkan berbagai faktor baik eksternal maupun internal untuk daerah tersebut. 


\section{ASPEK KESEHATAN}

Sanitasi dan pembuangan air limbah yang tidak memadai dapat mengarah ke penyebaran penyakit infeksi saluran cerna dan diare terutama pada negara yang kurang berkembang. ${ }^{16,18}$ Populasi larva $H$. illucens yang padat dilaporkan dapat menekan populasi larva Musca domestica L. sampai $94-100 \%{ }^{19}$

Salah satu bahan yang dihasilkan larva $H$. illucens untuk mempertahankan hidupnya berefek antimikroba. Choi et al. ${ }^{24}$ melakukan ekstraksi larva $H$. illucens dengan beberapa pelarut organik dan efek antimikroba tersebut ditentukan antara lain dengan metoda agar disk diffusion dan turbidometric assay. Ekstrak metanol mengindikasikan efek antimikroba terhadap Klebsiella pneumoniae, Neisseria gonorrhoeae, dan Shigella sonnei tetapi tidak terhadap mikroba Gram positif seperti Bacillus subtilis, Streptococcus mutans, dan Sarcina lutea.

Lalander ${ }^{18}$ meneliti kotoran manusia yang diberikan larva $H$. illucens dan mendapatkan penurunan konsentrasi Salmonella spp. sebesar $6 \log _{10}$ dalam 8 hari, dibandingkan penurunan pada kontrol $<2 \log _{10}$, tetapi tidak berefek terhadap Enterococcus spp, bacteriophage $\phi \mathrm{X} 174$, atau Ascaris suum ova.

Park et al. ${ }^{39}$ melaporkan bahwa imunisasi hemolimf $H$. illucens dengan Staphylococcus aureus memperlihatkan aktivitas broad spectrum yang kuat terhadap mikroba Gram negatif dan positif, termasuk methicillin-resistant Staphylococcus aureus (MRSA). Fraksi yang memperlihatkan efek MRSA dimurnikan dengan kolum C18HPLC dan terbukti mengandung antimicrobial peptide (AMP) baru yang dapat dikembangkan menjadi obat anti-infeksi.

Aktivitas makan selama perkembangan larva dapat menurunkan massa kotoran kering serta mereduksi berat rabuk sampai $42-56 \%{ }^{18}$ dan kandungan nitrogen sampai $62 \%{ }^{23}$ Myers $^{15}$ meneliti perkembangan larva $H$. Illucens pada kotoran manusia dan mendapatkan reduksi massa kotoran sebesar 33-58\%. Zakova ${ }^{6}$ melaporkan bahwa larva $H$. illucens dapat mereduksi berat sampah dengan persentase tertinggi terhadap berat sebelum perlakuan diperoleh untuk sampah tumbuhan 66,53\%, diikuti sampah sisa makanan $46,04 \%$, dan sampah kebun $8,47 \%$.

Penelitian dengan $H$. illucens memperlihatkan terdapatnya beberapa jenis mikroba yang diisolasi dari usus dan permukaan luar larva, antara lain: Micrococcus sp, Streptococcus sp, Bacillus sp, dan Aerobacter aerogenes. Mikrobamikroba ini dapat berefek terhadap manusia baik secara langsung atau tak langsung bila mengonsumsi daging hewan yang diberi pakan mengandung larva tersebut. Mengingat larva $H$. illucens secara alamiah ditemukan pada peternakan dan lingkungan yang kotor, maka pada proses rearing larva untuk pakan ternak perlu diperhatikan kondisi lingkungan agar larva tidak mengandung mikroba tersebut. ${ }^{25}$

\section{ASPEK EKONOMI}

Sampah masih menjadi masalah serius di banyak negara. Timbunan sampah dapat menjadi tempat berkembang biaknya serangga dan hewan pengerat, menimbulkan bau busuk, dan menghalangi aliran air yang mengakibatkan terjadinya banjir. ${ }^{16}$

Sampah organik menyusun $50 \%$ atau lebih dari sampah total. Sampah ini mengandung nilai nutrien dan energi tinggi sehingga digunakan sebagai sumber makanan oleh berbagai jenis serangga, termasuk H. Illucens. ${ }^{2,6,8,15,17}$

Penelitian Jaelani et al. $^{40}$ terhadap larva $H$. illucens yang diternak pada kotoran burung puyuh dan kotoran ayam (broiler dan petelur) memperlihatkan bahwa prepupa dapat digunakan sebagai sumber protein pakan untuk unggas karena mengandung protein kasar $>45 \%$ dengan kandungan asam amino yang lengkap. Lalander et al. ${ }^{18}$ yang menggunakan feses manusia untuk ternak larva $H$. illucens mendapatkan hasil yang serupa yaitu prepupa dengan kandungan materi kering $44 \%$, protein $42 \%$, lemak $35 \%$, serta asam 
amino esensial dan asam lemak. Prepupa telah digunakan sebagai pakan ternak yang bernilai gizi tinggi pada ayam, babi, tilapia, dan beberapa jenis ikan. ${ }^{16,20,41}$

Biofuel merupakan alternatif pilihan untuk menurunkan pemakaian bensin. Jenis-jenis biofuel antara lain bioetanol dan biodisel. $^{7} \mathrm{Li}$ et al. $^{7}$ meneliti biokonversi kotoran hewan (sapi) oleh $H$. illucens untuk menghasilkan komoditas biodisel dan produksi gula. Kotoran segar 1248,6 g dapat dikonversi menjadi 273,4 g residu kering oleh kerja 1200 larva $H$. illucens dalam 21 hari. Dari 70,8 g residu kering dapat dihasilkan 15,8 g biodisel. Setelah melalui proses ekstraksi, residu kering juga dapat dipakai unuk makanan ternak. Hidrolisis kotoran hewan yang telah dicerna oleh larva dapat menghasilkan gula.

Studi lanjut mengenai pemanfaatan $H$. illucens dalam aspek forensik, kesehatan, dan ekonomi sangat dibutuhkan termasuk peningkatan kemampuan $H$. illucens untuk mendaur ulang sampah organik dan kotoran (hewan dan manusia) serta perlakuan terhadap mikroba yang terkandung pada larva sehingga aman untuk digunakan sebagai pakan ternak.

\section{SIMPULAN}

Hermetia illucens dapat diimplikasikan pada perkiraan postmortem interval (PMI) dengan mempertimbangkan kondisi lingkungan di suatu daerah tertentu yang dapat memengaruhi durasi perkembangan larva.

Larva Hermetia illucens dapat mendaur ulang sampah organik menjadi energi bersih serta menurunkan polusi lingkungan akibat kotoran hewan dan manusia dalam waktu yang relatif singkat. Selain itu, populasi larva dapat menekan populasi Musca domestica dan pertumbuhan berbagai jenis mikroba.

Kandungan nutrien yang tinggi dari larva Hermetia illucens membuatnya ideal sebagai pakan hewan.

Penelitian pada berbagai kondisi geografik, lingkungan, dan musim perlu dikembangkan agar pemanfaatan Hermetia illucens dapat diaplikasikan secara lebih akurat dan ekonomis.

\section{DAFTAR PUSTAKA}

1. Byrd JH, Castner JL. 2010. Insects of Forensic Importance. In: Byrd $\mathrm{JH}$, Castner JL, editors. Forensic Entomology: The Utility of Arthropods in Legal Investigations (Second Edition). Boca Raton: CRC Press, 2010; p. 39-122.

2. Diener S, Solano SN, Gutierrez RF, Zurbrugg C, Tockner K. Biological treatment of municipal organic waste using black soldier fly larvae. Waste Biomass Valorization. 2011;2(4):35763.

3. Tomberlin JK, Sheppard DC, Joice JA. Selected life-history traits of black soldier flies (Diptera: Stratiomyidae) reared on three artificial diets. Ann Entomol Soc Am. 2002;95(3):379-86.

4. Tomberlin JK, Sheppard DC. Factors influencing mating and oviposition of black soldier flies (Diptera: Stratiomyidae) in a colony. J Entomol Sci. 2002;37(4):345-52.

5. Tomberlin JK, Adler PH, Myers HM. Development of the black soldier fly (Diptera: Stratiomyidae) in relation to temperature. Environ Entomol. 2009;38(3):930-4.

6. Zakova M, Borkovcova M. Hermetia illucens application in management of selected types of organic waste. The 2nd Electronic Interdisciplinary Conference, September 2-6, 2013. Internal Grant Agency (IGA) Faculty of Agronomy Mendelu No. IP 6/2013.

7. Li Q, Zheng L, Qiu N, Cai H, Tomberlin JK, Yu Z. Bioconversion of dairy manure by black soldier fly (Diptera: Stratiomyidae) for biodiesel and sugar production. Waste Management. 2011;31(6):1316-20, doi:10.1016/jwasman.2011.01.005.

8. Newton L, Sheppard C, Watson DW, Burtle G, Dove R. Using the black soldier fly, Hermetia illucens, as a value-added tool for the management of swine manure, Waste Management Programs, North Carolina State University. Available from: http://www.cals.nscu.edu/waste_mgt/s 
mithfield_prpjects/phase2report05/cd,w eb\%20files/A2.pdf. 2005.

9. Sheppard DC, Tomberlin JK, Joyce JA, Kiser BC, Somner SM. Rearing methods for the black soldier fly (Diptera: Stratiomyidae). J Med Entomol. 2002;39(4):695-8.

10. Kim W, Bae S, Park H, Park K, Lee S, Choi Y, et al. The larval age and mouth morphology of the black soldier fly, Hermetia illucens (Diptera: Stratiomyidae). Int $\mathrm{J}$ Indust Entomol. 2010;21(2):185-7.

11. Lord WD, Goff ML, Adkins TR, Haskell NH. The black soldier fly Hermetia illucens (Diptera: Stratiomyidae) as a potential measure of human post mortem interval: Observation and case histories. J Forensic Sci. 1994;39:215-22.

12. Tomberlin JK, Sheppard DC, Joice JA. Black soldier fly (Diptera: Stratiomyidae) colonization of pig carrion in South Georgia. J Forensic Sci. 2005;50(1):1-2.

13. Ndueze OU, Okiwelu SN, Umeozor OC, Noutcha MAE. Arthropod succession on wildlife carcasses in lowland rainforest, River State, Nigeria. European Journal of Experimental Biology. 2013;3(5):106-10.

14. Wangko S. Kajian Gelombang Suksesi Serangga Forensik pada Bangkai Hewan Coba di Kota Manado, Indonesia [Disertasi]. Manado: Universitas Sam Ratulangi, 2012.

15. Myers HM, Tomberlin JK, Lambert BD, Kattes D. Develpomnet of black soldier fly (Diptera: Stratiomyidae) larva fed dairy manure. Environ Entomol. 2008;37(1):11-5.

16. Diener S, Zurbrugg C, Tockner $K$. Conversion of organic material by black soldier fly larvae: establishing optimal feeding rates. Waste Manag Res. 2009;27:603-10.

17. Kalova M, Borkovcova M. Voracious larvae Hermetia illucens and treatment of selected types of biodegradable waste. Acta Universitatis Agriculturae et Silviculturae Mendelianae Brunensis. 2013;LXI(1):77-83.

18. Lalander C, Diener S, Magri ME, Zurbrugg C, Lindstrom A, Vinneras B. Faecal sludge management with the larvae of the black soldier fly
(Hermetia illucens) - from a hygiene aspect. Science of the Total Environment. 2013;458-460:312-8.

19. Sheppard DC. House fly and lesser house fly control utilizing the black soldier in manure management systems for caged lying hens. Environ Entomol. 1983;12:1439-42.

20. Bondari K, Sheppard DC. Soldier fly larvae as feed in commercial fish production. Aquaculture. 1981;24:103-9.

21. Newton GL, Sheppard DC, Watson DW, Burtle GJ, Dove CR, Tomberlin JK, et al. The black soldier fly, Hermetia illucens, as a manure management/ resource recovery tool. http://www. cals.nscu.edu/waste_mgt/natlcenter/san antonio/Newton.pdf.

22. Bradley SW, Sheppard DC. Housefly oviposisition inhibition by larvae of Hermetia illucens the black soldier fly. J Chem Ecol. 1984;10(6):853-9.

23. Sheppard DC, Newton GL, Thompson SA, Davis J, Gascho G, Bramwell K. Using soldier flies as a manure management tool for volume reduction, house fly control and reduction, house fly control and feedstuff production. In: Roland G, editor. Sustainable Agriculture Research and Education, Southern Region. Annual report. Sustainable Agriculture Research and Education, Southern Region, George Station, Griffin, Ga, 1998. P. 51-52.

24. Choi WH, Yun JH, Chu JP, Chu KB. Antibacterial effect of extracts of Hermetia illucens (Diptera: Stratiomyidae) larvae against Gramnegative bacteria. Entomological research. 2012;42(5):219-26.

25. Banjo AD, Lawal OA, Olusola OO. Bacteria associated with Hermetia illucens (Linaeus) Diptera: Stratiomyidae. Asian Journal of Microbiology, Biotecchnology \& Environmental Sciences Paper. 2005;7(3):351-4.

26. Triplehorn CA. Johnson NF. Borror and deLong's Introduction to the Study of Insects (Seventh Edition). Belmont: Thomson Brooks/Cole, 2005.

27. Gujarathi GR, Madhuri PK. Occurence of black soldier fly Hermetia illucens (Diptera: Stratiomyidae) in biocompost. 
Research Journal of Recent Sciences. 2013;2(4):65-66.

28. DuPonte MW, Larish LB. Soldier fly. Livestock Management Insect Pests Sept 2003, LM-10.7. Cooperative Exension Service, College of Tropical Agriculture and Human Resources University of Hawaii, Manoa.

29. Pujol-Luz JR, da Costa Francez PA, Ururahy-Rodrigues A, Constantino R. The black soldier-fly, Hermetia illucens (Diptera, Stratiomyidae), used to estimate the postmortem interval in a case in Amapa State, Brazil. J Forensic Sci. 2008;53(2):476-8.

30. Salleh AFM, Marwi MA, Jeffery J, Abd Hamid NA, Zuha RM, Omar B. A review of forensic entomology cases at Ipoh Hospital and Hospital Universiti Kebangsaan Malaysia for the year 2003. Indonesian J Legal For Sci. 2008;1(1):1-4.

31. Amendt J, Krettek R, Zehner R. Forensic entomology. Naturwissenscahften. 2004;91: 51-60.

32. Anderson GS, Vanlaerhoven SL. Initial studies on insect succession on carrion in southwestern British Columbia. Journal of Forensic Science, 1996;41(4):617-25.

33. DiMaio VJ, DiMaio D. Forensic Pathology (Second Edition). Boca Raton: CRC Press, 2001.

34. Gennard DE. Forensic Entomology: An Introduction. London: John Wiley \& Sons Ltd., 2007.
35. Goff ML. Early postmortem changes and stages of decomposition. In: Amendt J, Campobasso CP, Goff ML, Grassberger $\mathrm{M}$ (editors). Current Concepts in Forensic Entomology Dordrecht: Springer, 2010; p. 1-24.

36. Benecke M. A brief history of forensic entomology. Forensic Sci. Int. 2001;120:2-14.

37. Mahat NA, Zafarina Z, Jayaprakash PT. Influence of rain and malathion on oviposition and development of blowflies (Diptera: Calliphoridae) infesting rabbit carcasses in Kelantan, Malaysia. Forensic Sci Int. 2009;192:19-28.

38. May BM. The occurence in New Zealand and the life-history of the soldier fly Hermetia illucens (L.). New Zealand Journal Sci. 1961;4:55-65.

39. Park SI, Yoe J, Choe Y, Jang H, Yoe SM. Isolation and characterization of novel antimicrobial peptide from the black soldier fly, Hermetia illucens. [cited 2014 Mar 15]. Available from: http://esa.confex.com/esa/2011/webpro gram/Paper58119.html.

40. Jaelani A, Gunawan A, Widaninngsih $\mathbf{N}$. Biokonversi manure oleh maggot lalat black soldier dan lalat hijau. Media SainS. 2010;2(1):67-76.

41. Hale OM. Dried Hermetia illucens larvae (Diptera: Stratiomyidae) as feed additive for poultry. J Ga Entomol. 1973;8:16-20. 